of scientific books was stressed. The third section of the congress was devoted to general cultural talks, and the subjects dealt with in this section mainly comprised the history of science in the Arab nations, such as progress in mathematical and navigational sciences, by Kazwini, Ibn E1 Haytham, Khowarizmi, El Tousy, El Bayrouni, El Battani, Ibn Sena, Gaber Ibn Hayan and others.

During the congress, exhibitions were arranged: one dealing with modern materials organized by the United Nations Educational, Scientific and Cultural Organization, another with the history of science in the Arab nations, and a third with scientific books written in Arabic and other languages. The congress also arranged for visits to places of scientific interest, such as the Institute of Marine Biology at Alexandria, the Roman Museum, the Misr Company for Cotton Weaving, the Misr Company for Artificial Silk, and the Burg el Arab field for desert plants. Among the decisions made in the final meeting of the congress was a recommendation for the institution of an Arab Scientific Union to be initiated by the Arab Union Organization.

\section{WATER POLLUTION RESEARCH}

\section{REPORT FOR 1952}

$\mathrm{T}$ HE report of the Director of Water Pollution Research and that of the Water Pollution Research Board are contained in an interesting publication entitled "Water Pollution Research 1952"*. It is not possible in a short notice to indicate all the interesting work that is being done on this important subject, and the reports themselves should be consulted.

Work has continued on the effect of various substances on the disinfecting action of chlorine on bacteria in water, and methods have been improved for the enumeration of Streptococcus faecalis, an organism which is one of the indicators of fæcal pollution. Work has also been done on the removal of radioactive jodine discharged as a constituent of sewage in small amounts into streams after its use in medicine.

Work on sewage at Birmingham has confirmed that slow rotation of percolating filters lowers the biochemical oxygen demand of the effluent and considerably increases its nitrification. Other work on sewage has shown that a volume of filtering medium of 10 cubic yards for each $10-20$ persons gives effluents of very good quality. Experiments done in co-operation with the Gas Board have shown that spent liquor from the gasworks at Hinckley can be treated in a percolating filter in admixture with sewage, in a concentration up to 3 per cent, by volume, without causing much deterioration of the quality of the effluent. This proportion is very much higher than that possible when gas liquor of the ordinary type is used. The methods used at Hinckley for the treatment of hot gas by electrostatic precipitation, with the object of reducing the concentration of higher tar acids in the liquor, are described. Further work on this subject is in hand.

Work has also been done on industrial waste waters. In the treatment of black liquor resulting

*Department of Scientific and Industrial Research. Report of the Water Pollution Research Board, with the Report of the Director of Water Pollution Research for the Year 1952 . Pp. iv $+64+4$ plates. (London: H.M.S.O., 1953.) 2s, 6d. net. from the kiering of cotton, an active sludge has been developed which, when it is mixed with the neutralized liquor, causes rapid anaerobic fermentation with the evolution of gas containing about 80 per cent of methane. Experiments have also been done on methods of treating simple and complex metallic cyanides mixed with sewage. It has proved possible to obtain, from sewage containing potassium, zinc and cadmium cyanides in concentrations equivalent to a hundred parts of hydrogen cyanide per million, effluents which contained an average of less than $0 \cdot 2$ p.p.m. of cyanide. It has also been shown that the toxicity of potassium cyanide in small concentrations increases markedly as the concentration of oxygen in solution is reduced. This is important in the design of toxicity tests and in the effect on fish of toxic substances in rivers.

The largest section of the report discusses the work on the Thames Estuary. Among the subjects studied are the distribution of salt and fresh water, the effect of rough weather in raising the level of oxygen dissolved in the water, pollution by discharges of organic matter contained in streams, sewage effluents and industrial wastes, the particle size of deposits in the Estuary, the important effect of suspended solids on the biochemical oxygen demand of Estuary water, the inhibition by oxygen of bacterial reduction of sulphate to sulphide and the catalytic effect of mud in promoting oxidation of sulphide by oxygen in solution.

The presence of large quantities of foam in rivers has been reported from many places during the year, and work on this problem is contemplated. With regard to the problem of pollution of beaches by oil, investigations on methods of preventing this pollution, in which a number of oil companies are cooperating, is in progress. A special problem, not specifically mentioned in these reports, would seem to be the general effects of substances now being extensively used for the control of pests of crops. Since the end of 1952 Water Pollution Abstracts, published by H.M. Stationery Office, has issued 35,000 abstracts, and the size of this monthly publication was increased in 1953 to meet the large number of papers now being written in Britain and elsewhere on this subject.

\section{THE COSMOTRON AT THE BROOKHAVEN NATIONAL LABORATORY}

\section{$\mathrm{V}$}

ALUABLE information concerning nuclear forces and the properties of fundamental particles can be obtained from the study of the interaction of high-speed nucleons with nuclear matter and from the interaction of individual nucleons. The energies required for the production of the lighter $\pi$-mesons and the heavier mesons are known from cosmic-ray investigations, and it has been the endeavour of many workers to produce such mesons in the laboratory by means of particle accelerators. Already during 1946-47 several particle accelerators capable of producing particles with energies of $300-400 \mathrm{MeV}$., sufficient for $\pi$-mesons, were under construction; but the design of accelerators for production of the heavier mesons requiring energies of the order of $5,000 \mathrm{MeV}$. had not been investigated. 
In 1947 the Brookhaven National Laboratory, Upton, New York, after careful consideration of the scientific, economic and practical factors involved, concluded that the proton synchrotron was the best type of accelerator suitable for the purpose, and in 1948, with the financial assistance of the United States Atomic Energy Commission, the design and construction of the cosmotron was commenced. The assembly took nearly four years, and in Mry 1952 a proton beam of $1,000 \mathrm{MeV}$. energy was obtained. This was increased to $2,000 \mathrm{MeV}$. in the following month, and with suitable modifications to the pole windings it is confidently expected that $3,000 \mathrm{MeV}$. will finally be obtained. Machines capable of reaching higher energies are being constructed elsewhere; but the cosmotron was the first high-energy accelerator to be constructed and to be operated.

The work was directed initially by M. Stanley Livingston (Massachusetts Institute of Technology), then by Milton G. White (Princeton University), and finally by G. B. Collins, who is the present chairman and who joined the project in April 1950. A detailed description of the principle, construction and operation of the cosmotron is given in a series of articles, edited by M. Hildred Blewett, a member of the cosmotron staff, in the special cosmotron issue of the Review of Scientific Instruments $(24$, No. 9 ; September 1953). L. J. Haworth, director of the Brookhaven Laboratory, contributes a short foreword, and this is followed by a general review, by the editor, of the cosmotron, discussed component by component and giving data concerning the personnel, cost and basic parameters.

A ring-shaped magnet guides the particles on a circular path of radius $30 \mathrm{ft}$., and $\mathrm{a}$ radiofrequency electric accelerating field provides increments of energy to the protons which are injected initially into the cosmotron, at about $3.5 \mathrm{MeV}$., from a Van de Graaff accelerator. The maximum magnetic field is 14,000 gauss. The vacuum is maintained by twelve 20 -in. diffusion pumps at a minimum operating pressure of $5 \times 10^{-6} \mathrm{~mm}$. of mercury, and the volume evacuated is about $300 \mathrm{cu}$. ft. The other articles in the series are divided into sections dealing with the magnet, the pole-face windings, the radiofrequency system, the injection system, the vacuum system and the control system, respectively. Finally, three short papers desl with the cosmotron building, eddy-current phenomena and studies of injection phenomena in the cosmotron, respectively.

\section{ALEURONE LAYER IN BARLEY}

YN a comprehensive anatomical investigation of the 1 sleurone layer in the cultivated barley, J. Sawicki (Polska Akademia Umiejetnosci, No. 66, 1-59, pub. Krakow, 1952, with English summary) has examined 103 varieties, representing all the sub-species of Hordeum sativum collected in different parts of the world.

In these materials, the number of cell rows in the aleurone layer and its thickness were observed. The range of variability of these characters was studied to see if they could be used in the classification of barleys. The hereditary transmission of these characters was also investigated over a period of several years. It has been ascertained that the varieties examined show distinct differences in regard to both the characteristics studied. The mean number of cell rows in the aleurone layer of the different barley varieties ranges from $1 \cdot 64$ to $3 \cdot 11$, and the mean thickness of the aleurone layer from 49.94 to $110 \cdot 16$ microns.

Observations of the two characteristics in question on material from several years and from different climatic conditions showed that they exhibit $a_{0}$ com. paratively small variability due to the environmental conditions. A detailed analysis of variance of material of forty varieties from 1937, 1938 and 1947 cultures showed that as regards the number of the cell rows the varietal differences are responsible for 93.00 per cent of the total variation and for 85.60 per cent as regards thickness of the aleurone layer. The variation due to seasonal differences is very small : in the first case 0.60 per cent, and in the second 0.40 per cent of the total variation. The remaining amounts of variation are due to unknown causes (environmental changes). Similar results were obtained by analysis of the variation of the pedigree lines from 1947,1948 and 1949, indicating that there are no essential differences between the pedigree lines and the examined material of commercial varieties. The results obtained justify the view that the aleurone characters are comparatively constant and may therefore be used in classification.

It is held that the results of these investigations corroborate the earlier data of Orlow, who found that barleys endemic in the Asiatic centre of origin as a rule possess three rows, and those of the African centre two rows, of cells in the aleurone layer only. As the European varieties of cultivated barley show a similar differentiation, the possibility exists of explaining, in some cases, their primary origin.

\section{FORESTRY COMMISSION IN SCOTLAND}

TN a small illustrated pamphlet entitled "The Forestry Commission in Scotland" (recently published by the Forestry Commission) it is stated that the history of forestry in Scotland is a long one. Shakespeare in "Macbeth", for example, brought the Birnam Woods to Dunsinane, a difficult military position, and timber from the same Birnam Hill in Perthshire was used for helping the national effort during the Second World War. Great natural woods once covered most of Scotland; but through the years, fire, disease and the axe took a great toll. Later, many of the remaining forests were exploited for charcoal for iron-smelting purposes, followed by the spread of sheep-raising at the end of the eighteenth century.

It was the great inroads into the woods of the country, almost entirely privately owned, during the First World War that brought the Forestry Commission under the Forestry Act of 1919. The Commission was reconstituted by the Forestry Acts of 1945 and 1951. Under the 1945 Act the Commission was made subject to direction from the Minister of Agriculture and Fisheries and the Secretary of State for Scotland. In Scotland all land acquired through the Forestry Fund is vested in the Secretary of State.

Between the World Wars a great deal of planting was done by the Forestry Commission, but the resultant plantations were still too young to provide any contribution of value to the timber requirements of the Second World War. Once again it was the 